\begin{tabular}{lllll}
\hline Estudios de Economía Aplicada & Vol. 29-3 2011 & PÁgs. $845-862$ \\
\hline
\end{tabular}

\title{
Efficiency and Seasonality in the Balearic Hospitality Industry
}

\author{
ANTONI RIERA FONT \\ Departamento de Economia Aplicada, UNIVERSIDAD DE LAS ISLAS BALEARES y \\ Director del Centre de Recerca Econòmica (UIB - "SA NOSTRA"), ESPAÑA. E-mail: \\ antoni.riera@uib.es
}

AINA M. RIPOLL PENALVA

Centre de Recerca Econòmica (UIB · “SA NOSTRA”), ESPANAA. E-mail: aripollp@cre.sanostra.es

CATALINA N. JUANEDA SAMPOL

Departamento de Economía Aplicada, UNIVERSIDAD DE LAS ISLAS BALEARES, ESPAÑA.

E-mail: nati.juaneda@uib.es

\begin{abstract}
Efficiency is one of the most decisive factors in an industry's productivity and competitiveness. However, Spanish and international economic literature has given little attention to measuring efficiency in some fields of activity, like the lodging industry due to the intangible nature of its services. The aim of this paper is to measure the technical efficiency of a sample of fifty mid-range Balearic tourist accommodation units specializing in the sun and sand market using Data Envelopment Analysis (DEA) and to explain observed differences in the results according to seasonal patterns in tourism activities and other characteristics of the accommodation units.
\end{abstract}

Keywords: Efficiency, Data Envelopment Analysis, Hospitality Industry, Seasonality.

\section{Eficiencia y estacionalidad en la industria hotelera balear}

\section{RESUMEN}

La eficiencia es uno de los factores que incide de forma más decisiva sobre las ganancias de productividad y competitividad de una industria. Sin embargo, en algunos segmentos de actividad, como el de la hostelería, la medición de la eficiencia ha sido escasamente tratada por la literatura económica aplicada, tanto a nivel nacional como internacional, debido, en gran medida, al carácter intangible de las actividades de servicios. En este contexto, el presente trabajo tiene como objetivo medir la eficiencia técnica de una muestra de cincuenta establecimientos de alojamiento turístico de las Islas Baleares, a partir de la aplicación del analisis envolvente de datos (DEA) y explicar las diferencias observadas en los resultados de acuerdo al patrón estacional de la actividad turisitica y a otras características de los establecimientos de alojamiento considerados.

Palabras clave: Eficiencia, DEA, industria hotelera, estacionalidad.

JEL Clasification: C61, D24, M10

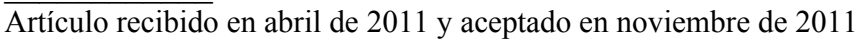

Artículo disponible en versión electrónica en la página www.revista-eea.net, ref. ə-29315 


\section{INTRODUCTION}

Business efficiency is one of the factors that is most directly influential on an industry's productivity gains and, therefore, on the competitiveness and longterm survival of companies. In some sectors, however, like the hospitality industry, economic literature has given little attention to measuring efficiency, mainly due to the intangible nature of its services (McLaughlin and Coffey, 1990; Grönroos and Ojasalo, 2004).

Growing competition in international tourism is strongly linked to the supply's capacity to adapt to a changing, increasingly discerning demand (Reynolds, 2003). Consequently, factors that have traditionally represented a strong competitive advantage in the provision of tourism services -prices and costsare no longer sufficient, particularly in destinations where the abandonment of a national monetary policy has led to the loss of an instrument that was occasionally able to alleviate falling competitiveness, albeit in a temporary shortterm way (Such and Zamora, 2006). Additionally, the increasing expansion of world tourism over the last two decades has led to a greater diversity of destinations, mainly in the form of a growing number of alternative destinations in the Mediterranean, such as North Africa, or the Near East and Eastern Europe, together with a boom in destinations in different parts of Asia and the Pacific (UNWTO, 2005). Thus, identifying factors that determine the long-term competitiveness of the lodging industry necessarily implies an analysis of productivity gains through increased business efficiency, reflected by the activities of management bodies and, more specifically, their capacity to manage and allocate available resources (Anderson et al., 2000). Thus, one research area of prime importance is the development of tools that can be used to quantify and explain levels of business efficiency, since they are a useful source of information in decision-making regarding factors that can guarantee positive mid and longterm results.

It must also be noted that, generally speaking, decision-making in tourism management takes place in a scenario characterized by a high degree of seasonality. Normally, seasonality is associated with two basic factors: climatological changes that affect the activities on offer at tourist destinations (sunshine and beaches, skiing etc) and certain social factors that are mainly attributable to policies on paid leave and school holidays. Numerous studies have tackled the problem of seasonality in a variety of different destinations, such as Aguiló and Sastre (1984) for the Balearic Islands, Yacoumis (1980) for Sri Lanka, Owens (1994) and Wilton and Wirjanto (1998) for Canada, Donatos and Zairis (1991) for Crete, and Jeffrey and Barden (1999) for English hotels. For the supply, seasonality represents a problem, not just because of low returns on investment and problems finding and hiring full-time staff (Ashworth and Thomas, 1999; 
Krakover, 2000), but also because of the temporal effects in terms of efficiency and the capacity of tourist facilities (Sutcliffe and Sinclair, 1980).

The aim of this study is to measure the efficiency of a sample of fifty accommodation units specializing in the sun and sand market in the Balearic Islands by applying Data Envelopment Analysis (DEA) techniques and analysing whether differences in efficiency can be detected based on the their different opening periods according to the seasonal pattern of the tourism activity. The results will also be explained according to the characteristics of the accommodation units in question. For the purpose of our study, a survey was specifically designed on the activities of Balearic accommodation centres in 2004 and sent out to units. This was used to gather data for the input and output-related variables used in the model, together with information on their opening period, certain main characteristics, and the context in which they operate.

In the following section, a brief description is given of the methodology that was used to measure efficiency, the sample group, and the variables that were chosen to carry out the study. In the third section, a presentation is made of the efficiency results, together with their interpretation, testing whether there are significant differences that can be attributed to seasonality or to other relevant variables. Finally, in the fourth section, an outline is made of the main conclusions of the study.

\section{AN ASSESSMENT OF EFFICIENCY}

\subsection{Methodological Background}

The efficient allocation of resources has become one of the traditional goals of economic science insofar as it attempts to study human behaviour as a relationship between ends and scarce means that have alternative uses (Robbins, 1992). A concern for productive efficiency is most prevalent in sectors like the hotel trade, given its high level of competition where inefficiency forces companies out of business.

Nonetheless, efficiency is a relative concept that emerged by comparing the behaviour of a set of similar businesses or decision-making units. Measurements are based on the distance that separates businesses from a frontier function, estimated by taking the best practices observed for the chosen set. The definition of this frontier is often approximated using parametric methods, such as stochastic frontiers, or non-parametric ones, as is the case of Data Envelopment Analysis (DEA) techniques. Data Envelopment Analyses involve the application of mathematical programming techniques. Introduced originally by Charnes, Cooper and Rhodes (1978) based on a seminal study by Farell (1957), 
a technical efficiency index is drawn up by resolving a mathematical optimization problem. ${ }^{1}$

The DEA technique chosen for this study makes it possible to assess efficiency in multioutput scenarios, while also ensuring a high level of flexibility by establishing relatively unrestrictive hypotheses in the definition of a production possibility set. All this is suited to circumstances in which the technology that relates the inputs and outputs of the production process is neither known nor observable, as is the case of the lodging industry. In this respect, most empirical efficiency analyses of the hotel sector have opted for DEA techniques as the assessment method (Morey and Dittman, 1995; Johns et al., 1997; Anderson et al., 2000; Avkiran, 2002; Brown and Ragsdale, 2002; Hwang and Chang, 2003; Barros and Alves, 2004; Chiang et al., 2004; Parra et al., 2004; Sigala et al., 2005; Barros, 2005; Wang et al, 2006). Among the major studies reviewed, Annex 1 summarizes those that address the preparation of the sample in order to ensure maximum homogeneity of the units, as well as the design of a specific questionnaire aimed to determine the most relevant outpus and inputs.

In specifying the optimization problem to be resolved, it is important to ensure the homogeneity of the accommodation units under analysis, to determine the type of returns to scale (constant or variable) and include them in the construction of the efficient frontier, and lastly to decide upon the approach to be taken when measuring efficiency (input or output). In this study, since the tourist accommodation units in question operate in a highly competitive market with few entrance and exit barriers, offering a tourist product with a very low level of differentiation, the assumption of constant returns to scale seems to be the most appropriate as a long-term equilibrium condition (Anderson et al., 1999; Henderson and Quandt, 1980), although most available empirical studies do not specify a particular hypothesis. Additionally, since in this case the tourist product is generally marketed and sold through tour operators and price is the main variable that determines sales, priority is understood to be given to cost control by adjusting the consumption of resources. All this supports the hypothesis that an input-oriented approach -which measures efficiency by assessing the necessary input ratio for the production of a certain level of output- is the most suitable one, in contrast with an output-oriented approach, which would be market-oriented and based on differentiation in relation to close rivals. ${ }^{2}$

Thus the model is formulated as follows:

\footnotetext{
${ }^{1}$ Farell himself had already suggested using linear programmes to draw up a technical efficiency index (Farell and Fieldhouse, 1962) and by Boles (1996).

${ }^{2}$ According to Färe and Lovell (1978), under the hypothesis that the production function displays constant returns to scale, the measurement of technical efficiency using an input or outputoriented approach is the same, although the interpretation of the results is not.
} 


$$
\begin{aligned}
& \min _{\theta, \lambda \mathrm{i}_{\mathrm{i}}} \theta_{\mathrm{i}} \\
& \text { s.a., } \\
& -y_{\mathrm{ij}}+\sum_{\mathrm{i}} \lambda_{\mathrm{i}} y_{\mathrm{ij}} \geq 0 \\
& \theta_{\mathrm{i}} x_{\mathrm{ir}}-\sum_{\mathrm{i}} \lambda_{\mathrm{i}} x_{\mathrm{ir}} \geq 0 \\
& \lambda_{\mathrm{i}} \geq 0 \\
& \mathrm{j}=1, . ., \mathrm{m} \quad \mathrm{r}=1, . ., \mathrm{k} \quad \mathrm{i}=1, . ., \mathrm{n}
\end{aligned}
$$

where $x_{i r}$ and $y_{i j}$ are the vectors of utilized input $(r)$ and produced output $(j)$, respectively, for each decision-making unit $(i), \lambda$ is a weighting vector used for comparison purposes with all remaining decision-making units, and $\theta$ is a scalar whose minimum value indicates the said unit's level of technical efficiency.

The aim is to identify a linear combination of other units, for each decisionmaking unit, capable of producing at least the same amount of outputs while consuming fewer inputs. Thus it can be inferred that if the said linear combination does not exist, the decision-making unit is efficient $\left(\theta_{i}=1\right)$, while in the opposite case the decision-making unit displays a certain level of inefficiency $\left(1-\theta_{i}\right)$ in relation to its reference group.

\subsection{Data Set and Selected Variables}

In this study, a homogeneous sample of 50 mid-range tourist accommodation ( 3 star) units were used, 22 of them hotels and 28 apartment hotels. All the units are located in coastal areas of the Balearic Islands and are clearly oriented toward the sun and sand holiday market, offfering a very standardized and seasonal product. The necessary data for our analysis was drawn from a specifically designed questionnaire distributed afther the begining of the high sesason. The survey gathered information for the input and output variables used in the model, together with the accommodation units' yearly opening period (thus making it possible to measure the seasonality of the supply) and other relevant variables for interpreting the results (certain characteristics of the accommodation units and the context in which they operated, some of which are shown in Table 1).

Given the non-parametric nature of DEA techniques, it is crucial to select the right variables since it largely affects the results of the estimated model because robustness cannot be statistically tested (Pedraja and Salinas, 2004). ${ }^{3}$

\footnotetext{
${ }^{3}$ This problem is being tackled in numerous studies aimed at equipping DEA techniques with properties that bring it in line with econometric models (see Simar and Wilson [2000] for a summary of the current state of affairs).
} 
Table 1

Main characteristics of the accommodation units

\begin{tabular}{|c|c|c|c|c|c|c|}
\hline $\begin{array}{c}\text { Accommodation } \\
\text { unit }\end{array}$ & $\begin{array}{c}\% \\
\text { Profits/Income }\end{array}$ & $\begin{array}{c}\% \\
\begin{array}{c}\text { Repeat } \\
\text { visits }\end{array}\end{array}$ & $\begin{array}{l}\text { No. years with } \\
\text { main tour } \\
\text { operator }\end{array}$ & $\begin{array}{l}\text { No. } \\
\text { beds }\end{array}$ & $\begin{array}{c}\text { Months } \\
\text { open }\end{array}$ & $\begin{array}{c}\% \\
\text { Majority } \\
\text { nationality }\end{array}$ \\
\hline E1 & $9 \%$ & $15 \%$ & 7 & 312 & 6 & $80 \%$ \\
\hline E2 & $2 \%$ & $30 \%$ & - & 268 & 10 & $100 \%$ \\
\hline E3 & $20 \%$ & $20 \%$ & 5 & 226 & 12 & $40 \%$ \\
\hline E4 & $14 \%$ & $30 \%$ & 8 & 178 & 10 & $90 \%$ \\
\hline E5 & $28 \%$ & $20 \%$ & 10 & 386 & 6 & $90 \%$ \\
\hline E6 & $27 \%$ & $15 \%$ & 3 & 292 & 7 & $50 \%$ \\
\hline E7 & $30 \%$ & $5 \%$ & 3 & 376 & 7 & $80 \%$ \\
\hline E8 & $35 \%$ & $20 \%$ & 8 & 694 & 7 & $50 \%$ \\
\hline E9 & $36 \%$ & $30 \%$ & 8 & 555 & 7 & $70 \%$ \\
\hline E10 & $30 \%$ & $25 \%$ & 3 & 328 & 6 & $55 \%$ \\
\hline E11 & $35 \%$ & $20 \%$ & 2 & 570 & 6 & $100 \%$ \\
\hline E12 & $32 \%$ & $10 \%$ & 4 & 552 & 11 & $67 \%$ \\
\hline E13 & $18 \%$ & $15 \%$ & 4 & 432 & 10 & $94 \%$ \\
\hline E14 & $34 \%$ & $7 \%$ & 6 & 363 & 9 & $46 \%$ \\
\hline E15 & $40 \%$ & $5 \%$ & 6 & 152 & 5 & $55 \%$ \\
\hline E16 & $52 \%$ & $7 \%$ & 6 & 188 & 7 & $93 \%$ \\
\hline E17 & $46 \%$ & $4 \%$ & 6 & 544 & 6 & $82 \%$ \\
\hline E18 & $6 \%$ & $15 \%$ & 10 & 400 & 6 & $96 \%$ \\
\hline E19 & $8 \%$ & $10 \%$ & 10 & 237 & 6 & $98 \%$ \\
\hline E20 & $25 \%$ & $20 \%$ & 3 & 220 & 6 & $40 \%$ \\
\hline E21 & $38 \%$ & $15 \%$ & - & 336 & 6 & - \\
\hline E22 & $25 \%$ & - & - & 220 & 6 & $40 \%$ \\
\hline E23 & $18 \%$ & - & - & 400 & 7 & - \\
\hline E24 & $3 \%$ & - & - & 163 & 6 & - \\
\hline E25 & $23 \%$ & - & - & 370 & 6 & - \\
\hline E26 & $20 \%$ & - & - & 165 & 6 & - \\
\hline E27 & $14 \%$ & - & - & 362 & 6 & - \\
\hline E28 & $23 \%$ & $13 \%$ & 30 & 564 & 10 & $89 \%$ \\
\hline E29 & $52 \%$ & $13 \%$ & 6 & 198 & 10 & $87 \%$ \\
\hline E30 & $13 \%$ & $20 \%$ & 22 & 292 & 10,5 & $87 \%$ \\
\hline E31 & $57 \%$ & $20 \%$ & 24 & 156 & 10,5 & $96 \%$ \\
\hline E32 & $24 \%$ & $25 \%$ & 28 & 474 & 9 & $62 \%$ \\
\hline E33 & $38 \%$ & $14 \%$ & 26 & 710 & 6 & $61 \%$ \\
\hline E34 & $14 \%$ & $3 \%$ & 15 & 471 & 5 & $40 \%$ \\
\hline E35 & $32 \%$ & - & - & 650 & 7 & - \\
\hline E36 & $40 \%$ & - & - & 900 & 7 & - \\
\hline E37 & $33 \%$ & - & - & 812 & 6 & - \\
\hline E38 & $34 \%$ & - & - & 350 & 6 & - \\
\hline E39 & $30 \%$ & - & - & 452 & 9 & - \\
\hline E40 & $26 \%$ & - & - & 302 & 7 & - \\
\hline E41 & $30 \%$ & - & - & 930 & 9 & - \\
\hline E42 & $23 \%$ & - & 7 & 596 & 7 & $61 \%$ \\
\hline E43 & $17 \%$ & - & 5 & 199 & 6 & $48 \%$ \\
\hline E44 & $22 \%$ & $11 \%$ & 7 & 520 & 6 & $48 \%$ \\
\hline E45 & $53 \%$ & $15 \%$ & 25 & 480 & 7 & $42 \%$ \\
\hline E46 & $29 \%$ & $25 \%$ & 15 & 564 & 6 & $75 \%$ \\
\hline E47 & $19 \%$ & $15 \%$ & 30 & 310 & 12 & $60 \%$ \\
\hline E48 & $18 \%$ & - & 40 & 157 & 6 & $48 \%$ \\
\hline E49 & $2 \%$ & $40 \%$ & 29 & 175 & 8 & $99 \%$ \\
\hline E50 & $39 \%$ & - & - & 414 & 7 & $67 \%$ \\
\hline
\end{tabular}

Source: Own elaboration. 
In this respect, the output was approximated using the following variables, which are understood to be representative of the service offered by the accommodation units:

- $\mathrm{y}_{1}$ : the ratio between the operating income per room of each accommodation unit and the mean value for the sector.

- $y_{2}$ : the number of stays that were sold.

- $y_{3}$ : non-accommodation-related operating income.

At the same time, with respect to the selection of the production factors, the importance of the human factor in the provision of hotel service justifies the choice of personnel costs as a determinant of the product, while the current expenditure on goods and services has been considered representative of resource consumption. It has also considered the capital factor taken into account the number of beds available. The utilized inputs were included based on the following variables:

- $\mathrm{x}_{1}$ : staff expenses.

- $\mathrm{x}_{2}$ : non-staff-related operating expenses.

- $\mathrm{x}_{3}$ : available beds.

\section{EMPIRICAL RESULTS}

When the model specified in [1] was estimated, the results that were obtained (shown in Table 2) give the technical efficiency value (CCR) of all the units in the sample. In this case, the efficient frontier is demarcated by 15 accommodation units, which have a technical efficiency value equal to one. The remaining accommodation units have either a higher or lower level of efficiency, depending on their distance from the efficient frontier.

In aggregate terms, the mean value of the technical efficiency index for the whole sample is 0.876 . If we just take accommodation units that display some level of inefficiency, the mean value drops to 0.823 , which implies that, on average, these centres should reduce their consumption of inputs by $17.7 \%$ to reach the frontier and thus be considered efficient. It should be noted that the high level of overall efficiency that was obtained is coherent with the reality of the Balearic tourist industry, given its mature, highly competitive nature and the fact that it has achieved a long-run equilibrium with highly inefficient units having gone out of business ${ }^{4}$. To give an example, accommodation unit E34 has

\footnotetext{
${ }^{4}$ The overall mark that is obtained is directly proportional to the number of variables incorporated in the model and the homogeneity of the sample under analysis. Thus, the result obtained for the Balearic Islands is considerably higher than that of other studies of other regions or countries of the world that include a similar number of variables (Anderson et al., 2000; Hwang and Chang, 2003; Pestana and Mascarenhas, 2005; Wang et al., 2006).
} 
the lowest level of efficiency (0.537), indicating an overuse of inputs. This can be overcome by reducing the inputs to $46.3 \%$. For the purposes of comparison, E34 can take the accommodation units in its reference group as a guide (E8, E36 and E31). They are efficient accommodation units that achieve a level of output similar to that of E34 with fewer inputs.

Table 2

Technical efficiency scores of the Balearic lodging industry

\begin{tabular}{ccccc}
\hline $\begin{array}{c}\text { Accommodation } \\
\text { unit }\end{array}$ & $\begin{array}{c}\text { CCR } \\
\text { efficiency }\end{array}$ & Reference group & Frequency & Ranking \\
\hline E31 & 1.000 & E31 & 22 & 1 \\
E12 & 1.000 & E12 & 18 & 2 \\
E20 & 1.000 & E20 & 15 & 3 \\
E16 & 1.000 & E16 & 13 & 4 \\
E41 & 1.000 & E41 & 13 & 5 \\
E8 & 1.000 & E8 & 12 & 6 \\
E49 & 1.000 & E49 & 11 & 7 \\
E9 & 1.000 & E9 & 9 & 8 \\
E3 & 1.000 & E3 & 4 & 9 \\
E36 & 1.000 & E36 & 3 & 10 \\
E38 & 1.000 & E38 & 3 & 11 \\
E46 & 1.000 & E46 & 3 & 12 \\
E50 & 1.000 & E50 & 3 & 13 \\
E22 & 1.000 & E22 & 2 & 14 \\
E1 & 1.000 & E1 & 1 & 15 \\
E23 & 0.993 & E41.E20.E12 & 0 & 16 \\
E18 & 0.990 & E41.E38 & 0 & 17 \\
E4 & 0.982 & E31.E16.E3 & 0 & 18 \\
E45 & 0.948 & E46.E12.E9.E31 & 0 & 19 \\
E42 & 0.944 & E20.E36.E41.E8 & 0 & 20 \\
E15 & 0.941 & E20.E8.E31 & 0 & 21 \\
E47 & 0.937 & E12.E16.E9.E49 & 0 & 22 \\
E40 & 0.931 & E31.E41.E20.E12 & 0 & 23 \\
E37 & 0.925 & E41.E38 & 0 & 24 \\
E11 & 0.920 & E9.E46.E31.E50.E8 & 0 & 25 \\
E26 & 0.913 & E31.E8.E16.E20 & 0 & 26 \\
E27 & 0.903 & E41.E20.E12.E49 & 0 & 27 \\
E13 & 0.865 & E41.E31.E12 & 0 & 28 \\
E14 & 0.861 & E46.E50.E8.E31.E12 & 0 & 29 \\
E24 & 0.857 & E49.E3.E20.E31 & 0 & 30 \\
E6 & 0.851 & E31.E12.E16.E9 & 0 & 31 \\
E19 & 0.850 & E31.E38.E20 & 0 & 32 \\
E7 & 0.844 & E49.E8.E12.E31.E20 & 0 & 33 \\
E2 & 0.834 & E16.E3.E49 & 0 & 34 \\
\hline & & & & \\
\hline
\end{tabular}


Table 2 (continue)

Technical efficiency scores of the Balearic lodging industry

\begin{tabular}{ccccc}
\hline $\begin{array}{c}\text { Accommodation } \\
\text { unit }\end{array}$ & $\begin{array}{c}\text { CCR } \\
\text { efficiency }\end{array}$ & Reference group & Frequency & Ranking \\
\hline E30 & 0.801 & E12.E16.E9.E49 & 0 & 37 \\
E39 & 0.798 & E12.E20.E3 & 0 & 38 \\
E25 & 0.791 & E8.E41.E20.E31.E12 & 0 & 39 \\
E10 & 0.787 & E49.E31.E9.E12.E16 & 0 & 40 \\
E35 & 0.773 & E49.E41.E20.E8 & 0 & 41 \\
E43 & 0.744 & E22.E16.E9 & 0 & 42 \\
E44 & 0.742 & E8.E36.E31.E41 & 0 & 43 \\
E5 & 0.687 & E12.E31.E20.E41 & 0 & 44 \\
E33 & 0.662 & E8.E20.E41.E31.E12 & 0 & 45 \\
E28 & 0.661 & E12.E16.E9.E49 & 0 & 46 \\
E48 & 0.660 & E16.E31.E50 & 0 & 47 \\
E32 & 0.626 & E9.E12.E16.E49 & 0 & 48 \\
E17 & 0.611 & E12.E31.E20.E41 & 0 & 49 \\
E34 & 0.537 & E8.E36.E31 & 0 & 50 \\
\hline
\end{tabular}

Source: Own elaboration.

From the results that were obtained, shown in Table 3, it can be inferred that, indeed, at a $10 \%$ significance level there are differences in efficiency depending on the opening period of the accommodation unit. Thus, the optimal management strategy seems to be to extend the accommodation unit's period of activity as long as possible throughout the year, competing to attract as many tourists as possible, not just in the high season but during the rest of the year.

Table 3

Comparison of technical efficiency scores

\begin{tabular}{lccccc}
\hline \multicolumn{1}{c}{ Variable } & Groups & $\mathbf{n}$ & $\begin{array}{c}\text { Technical } \\
\text { efficiency }\end{array}$ & $\begin{array}{c}\text { Standard } \\
\text { deviation }\end{array}$ & $\begin{array}{c}\text { Mann- } \\
\text { Whitney }\end{array}$ \\
\hline Months open & $5-6$ & 23 & 0.840 & 0.141 & -1.786 \\
& $7-12$ & 27 & 0.906 & 0.109 & $(0.074)^{\mathrm{a}}$ \\
\%Repeat visits & $<15 \%$ & 12 & 0.796 & 0.152 & -2.049 \\
& $>15 \%$ & 21 & 0.907 & 0.113 & $(0.040)^{\mathrm{b}}$ \\
Years with main tour operator & $<10$ & 21 & 0.900 & 0.112 & -1.884 \\
& $>10$ & 13 & 0.797 & 0.166 & $(0.059)^{\mathrm{a}}$ \\
\%Profits/Income & $<25 \%$ & 22 & 0.847 & 0.137 & -1.684 \\
\multirow{2}{*}{ No. of beds } & $>25 \%$ & 28 & 0.898 & 0.118 & $(0.092)^{\mathrm{a}}$ \\
& $<350$ & 23 & 0.900 & 0.100 & -0.957 \\
& $>350$ & 27 & 0.855 & 0.146 & $(0.338)$ \\
\hline
\end{tabular}

${ }^{a} 90 \%$ significance level

${ }^{b} 95 \%$ significance level

Source: Own elaboration. 
It is important, however, to qualify the previous statement, because the makeup of the Balearic tourist product and certain characteristics of the accommodation units can, to a greater or lesser extent, condition their ability to attract visitors once the high season is over, thus affecting decision-making. Thus certain factors that are hard to modify in the short and mid term influence the likelihood of a hotel opening outside the high season, such as its location in terms of its distance from the island's capital and the availability of services for activities carried out by tourists during the mid and low seasons (Capó et al, 2007).

Nonetheless, it can seen that improving the quality of services offered by accommodation units has positive consequences in terms of efficiency. From the tests that were performed, the accommodation units with the highest efficiency values are those that attract a significantly higher percentage of repeat visitors. ${ }^{5}$ Evidently, smoothing drops in demand by attracting a loyal client port-folio is fundamental, not only because it has a positive effect on the profit and loss account but because it also facilitates better planning, savings on resources and, in the last instance, improved efficiency. In this sense, it is important to note that, according to data for the sample, the repeat visitation rate is both directly and positively related to accommodation units with a higher concentration of a limited number of nationalities. Thus specializing in a certain market makes it possible to offer a better relative standard of service, since this service can be better adapted to suit guests' expectations, leading to improved satisfaction and consequently the degree of loyalty shown by the percentage of recurrence, which ultimately determines the yield obtained. ${ }^{6}$ However, it must also be taken into account that concentrating on a certain market means more exposure to fluctuations in demand that occur in the tourists' country of origin.

In contrast with the previous arguments, in some cases ensuring the loyalty of tour operators, the main marketing and sales channel for Balearic tourist products, does not lead to higher efficiency values. This relationship is clearly understood within the Balearic tourist market, heavily dependent on few tourist markets in which the concentration of intermediaries has been growing in recent years. Threrefore, the results that were obtained show that accommodation units that maintain a longer-lasting relationship with the main tour operator they work with display lower efficiency ratios. This could be associated with a sales management approach lacking in dynamism where agreements are maintained wi-

\footnotetext{
${ }^{5}$ The correlation coefficient between the accommodation centre's level of specialization in certain nationalities and the repeat visitation rate is 0.31 .

${ }^{6}$ Although, the positive relationship, widely discussed in the tourist literature, between repetition, service quality and satisfaction (see, among others, Appiah-Adu et al., 2000, Baker and Crompton, 2000; Tian-Cole and Crompton, 2003) suggests the inclusion of these variables in modeling as an output, the complexity of measuring it is extremely difficult.
} 
thout any possibility of improving on initial conditions because the accommodation unit does not seek alternatives to the main tour operator.

Whatever the case, the results confirm the abundant literature that points to higher efficiency levels immediately leading to better profit and loss accounts (Morey and Dittman, 1995; Brown and Dev, 1999). Thus accommodation units with higher profit levels in proportion to the income they receive are those that display better efficiency levels, once again confirming that differences in efficiency are attributable to the management capacity of those who run them.

Despite all this, it is worth considering whether the differences in efficiency that were observed might be attributable to the fact that inefficient units operate at a suboptimal scale. However, the tests that were performed do not reveal statistically significant differences in efficiency rates according to the size of the accommodation units under analysis, supporting the hypothesis of constant returns to scale adopted in the formulation of the model.

\section{CONCLUSIONS}

Using Data Envelopment Analysis (DEA) techniques, this study measured the level of technical efficiency of a set of 50 mid-range tourist accommodation units located in coastal areas of the Balearic Islands with a sun and sand market orientation. In terms of efficiency, the results reveal a high level of overall efficiency coherent with the mature, competitive nature of the region's tourist industry.

One of the main peculiarities of tourism in the Balearic Islands must be its strong seasonal pattern: a phenomenon that has led to the segmentation of the financial year into three seasons with different levels of activity, since most of the visitors come in the summer months. This forces management to decide on the yearly opening period for their accommodation units.

According to the results that were obtained, the variable that captures the number of months' activity was significant in as much as it was proven that longer opening periods lead to higher levels of efficiency and, additionally, to greater client loyalty. Nonetheless, it must also be added that factors relating to the characteristics of the accommodation units and the context in which it operates also condition the opening period, explaining the differences in efficiency that were observed.

An awareness of efficiency levels is mainly useful thanks to the information that it provides for planning marketing strategies. From this point of view, any initiative that helps offset a shrinking demand and increases the rate of repeat visits, while encouraging a constant search for sales channels other than the usual tour operator, will lead to the improved efficiency of the accommodation units and to higher profits. At the same time, the efficiency analysis that was 
performed is useful in helping management to assess the position of the accommodation units in relation to their rivals, in terms of the resources that are used to produce one unit of output, so that benchmarking studies can be carried out with a view to adopting "best-in-class" practices.

It is important to highlight how complex it is to incorporate the different variables that determine the level of efficiency of a tourist accommodation unit, given the intangibility of its output, the simultaneous nature of the provision and consumption of the service, and the scarcity of indicators that include quality parameters and take into account issues as significant as product differentiation and service management.

Lastly, neither should we overlook the limitations of DEA techniques since to a certain extent they condition the interpretation of the results. Thus the level of efficiency that is obtained for each accommodation unit can only be interpreted in relative terms, because it is dependent on the sample group. However, since decision-making units with a high degree of homogeneity are required for DEA techniques -a factor that has been carefully observed in this study- this guarantees the comparability of the results.

\section{REFERENCES}

AGUILÓ, E., SASTRE, A. (1984): "La medición de la estacionalidad del turismo: el caso de Baleares" in Estudios Turísticos, 81: pp. (79-88).

ALI, A. I. (1994): "Computacional aspects of DEA". En: Charnes, Cooper, Lewin and Seiford (eds.), Data envelopment analysis: theory, methodology and applications. Boston: Kluwer Academic Publishers.

ANDERSON , R.; FISH, M.; XIA, Y. and MICHELLO, F. (1999): "Measuring efficiency in the hotel industry: A stochastic frontier approach" in Hospitality Management, 18 (1): pp. (45-47).

ANDERSON, R.; FOK, R. and SCOTT, J. (2000): "Hotel Industry Efficiency: An Advanced Linear Programming Examination" in American Business Review, 18 (1): pp. (40-48).

APPIAH-ADU, K; FYALL, A. and SINGH, S. (2000). "Marketing culture and customer retention in the tourism industry" in The Service Industries Journal, 20: pp. (95-113).

ASHWORTH, J. and THOMAS, B. (1999): "Patterns of seasonality in employment in tourism in the UK" in Applied Economic Letters, 6: pp. (735-739)

AVKIRAN, N. (2002): "Monitoring Hotel Performance" in Journal of Asia Pacific Bussines, 4(1): pp. (51-66). 
BAKER, D.A. and CROMPTON, J.L. (2000): "Quality, satisfaction and behavioural intentions" in Annals of Tourism Research, 27(3): pp. (785-804).

BARROS, C. (2005): "Measuring efficiency in the hotel sector" in Annals of Tourism Research, 32 (2): pp.(456-477).

BARROS, C.P. and ALVES, F.P. (2004): "Productivity in the Tourism Industry" in International Advances in Economics Resources, 10(3): pp. (215-225).

BOLES, J.N. (1966): "Efficiency Squared-Efficient Computation of Efficiency Indexes" in Proceedings of the Thirty Ninth Annual Meeting of the Western Farm Economics Association: pp. (137-242).

BROWN, J.R. and DEV, C. (1999): "Looking Beyond RevPar" in Cornell hotel Restaurant and Administration Quarterly, 40 (2): pp. (23-33).

BROWN, J.R. and RAGSDALE, C.T. (2002): "The competitive market efficiency of hotel brands: an application of Data Envelopment Analysis" in Journal of Hospitality \& Tourism Research, 26 (4): pp. (332-360).

CHARNES, A.; COOPER, W. and RHODES, E. (1978): "Measuring the Efficiency of Decision-making Units" en European Journal of Operations Re-search, 2 (6): pp. (429-444).

CHIANG, W.; TSAI, M. and WANG, L. (2004): "A DEA Evaluation of Taipei Hotels" in Annals of Tourism Research, 31 (3): pp. (712-715).

CONSELLERIA DE TURISME (2005) El turisme a les Illes Balears. Dades informatives 2004. Ed. CITTIB

DONATOS, G. and ZAIRIS, P. (1991): "Seasonality of foreign tourism in the Greek island of Crete" in Annals of Tourism Research, 18: pp. (515-519)

FÄRE, R. and LOVELL, C.A.K. (1978): "Measuring the Technical Efficiency of Production" in Journal of Economic Theory, 19: pp. (150-162).

FARRELL, M.J. (1957): "The Measurement of Productive Efficiency" in Journal of the Royal Statistical Society, Series A, 120 (3): pp. (253-290).

FARRELL, M.J. and FIELDHOUSE, M. (1962): "Estimating Efficient Production Functions under Increasing Returns to Scale" in Journal of the Royal Statistical Society, 125: pp. (252-267).

GRÖNROOS, C. and OJASALO, K. (2004): "Service productivity. Towards a conceptualization of the transformation of inputs into economic results in services" in Journal of Business Research, 57 (4): pp. (414-423).

HENDERSON, J.M. and QUANDT, R.E. (1980): Microeconomic Theory: A Mathematical Approach ( $3^{\mathrm{a}}$ ed.). Nueva York: McGraw-Hill.

HWANG,S. and CHANG, T. (2003): "Using Data Envelopment Analysis to Measure Hotel Managerial Efficiency Change in Taiwan" in Tourism Management, 24: pp. (357-369).

JOHNS, N.; HOWCROFT, B. and DRAKE, L. (1997): "The Use of Data Envelopment Analysis to Monitor Hotel Productivity" in Progress in Tourism and Hospitality Research, 3 (2): pp. (119-227). 
JEFFREY, D. and BARDEN, R. (1999): "An analysis of the nature, causes and marketing implications of seasonality in the occupancy performance of English hotels" in Tourism Economics, 5: pp. (69-91).

KRAKOVER, S. (2000): "Partitioning seasonal employment in the hospitality industry" in Tourism Management, 21: pp. (461-471).

MCLAUGHLIN, C. and COFFEY, S. (1990): Measuring Productivity in Services. International Journal of Service Industry Management, 1 (1).

MOREY, R. and DITTMAN, D. (1995): "Evaluating a Hotel GM's Performance: A Case Study in Benchmarking" in Cornell hotel Restaurant and Administration Quarterly, 36 (5): pp. (30-35).

OWENS, D.J. (1994): "The all-season opportunity for Canada's resorts" in Cornell Hotel and Restaurant Administration Quarterly, 35 (5): pp. (28-41)

PARRA, F.; VICENTE, J.A; BELTRÁN, M. and FERNÁNDEZ, O. (2004): "Nivel de eficiencia de la productividad en los establecimientos turisticos de Baleares". In: Comportament de la productivitat i la competitivitat de les Illes Balears. Palma: Consell Econòmic i Social de les Illes Balears, pp. (143-183).

PEDRAJA, F. and SALINAS, J. (2004): "La evaluación de la eficiencia en el sector público mediante aproximaciones no paramétricas: algunas reflexiones metodológicas". In: Rueda, N. (coord.): Evaluación de la eficiencia del sector público. Vías de aproximación. Madrid: Fundación de las Cajas de Ahorros.

PESTANA, C. and MASCARENHAS, M.J. (2005): "Technical and allocative efficiency in a chain of small hotels" in Hospitality Management, 24: pp. (415436).

REYNOLDS, D. (2003): "Hospitality-Productivity assessment using DEA" in Cornell Hotel and Restaurant Administration Quarterly, 44 (2).

SIGALA, M.; JONES, P.; LOCKWOOD, A. and AIREY, D. (2005): "Productivity in Hotels: a Stepwise Data Envelopment Analysis of Hotels' Room Division Processes" in The Service Industries Journal, 25 (1): pp. (61-81).

SIMAR, L. and WILSON, P. (2000): "Statistical Inference in Nonparametric Frontier Models: The State of Art" in Journal of Productivity Analysis, 13 (1): pp. (49-78).

SUCH, M.J. and ZAMORA, M.M. (2006): "Spanish productivity: a regional approach" in Annals of Tourism Research, 33 (3): pp. (666-683).

SUTCLIFFE, C.M. and SINCLAIR, M.T. (1980): "The measurement of seasonality within the tourist industry: an application to tourist arrivals in Spain" in Applied Economics, 12 (4): pp. (429-441).

TIAN-COLE, S. and CROMPTON, J. (2003): "A conceptualisation of the relationship between service quality and service satisfaction, and their links to destination selection" in Leisure Studies, 22 (1): pp. (65-80).

UNWTO (2005): Making tourism more sustainable. A guide for policy makers. Paris: United Nations Environmental Programme. 
WANG, F.; HUNG, W and SHANG, J (2006): "Measuring the cost efficiency of international tourist hotels in Taiwan" in Tourism Economics, 12 (1): pp. (520).

WILTON, D. and WIRJANTO, T. (1998): An analysis of the seasonal variation in the national tourism indicators.Canadian Tourism Commission.

YACOUMIS, J. (1980): "Tackling seasonality: the case of Sri Lanka" in Tourism Management, 1: pp. (84-98). 
Annex 1

Review of Input and Output Variables Used in the Dea Literature

\begin{tabular}{|c|c|c|c|}
\hline & Unit & Input variables & Output variables \\
\hline $\begin{array}{l}\text { Wang et al. } \\
\qquad(2006)\end{array}$ & $\begin{array}{c}49 \text { hotels Taiwan, } \\
2001\end{array}$ & $\begin{array}{l}\text { - Full-time workers in the accommodation } \\
\text { department } \\
\text { - Number of rooms } \\
\text { - Dining and bar area } \\
\text { - Full-time workers in the catering } \\
\text { department }\end{array}$ & $\begin{array}{l}\text { - Income from rental of } \\
\text { rooms } \\
\text { - Revenue from food and } \\
\text { bevarages } \\
\text { - Other income }\end{array}$ \\
\hline $\begin{array}{l}\text { Barros } \\
(2005)\end{array}$ & $\begin{array}{l}42 \text { hotels } \\
\text { Portugal, } \\
1999-2001\end{array}$ & $\begin{array}{l}\text { - Full-time workers } \\
\text { - Staff costs } \\
\text { - Number of rooms } \\
\text { - Total area of the hotel } \\
\text { - Book value of property } \\
\text { - Operating expenses } \\
\text { - External expenses }\end{array}$ & $\begin{array}{l}\text { - Sales } \\
\text { - Number of clients } \\
\text { - Number of stays }\end{array}$ \\
\hline $\begin{array}{l}\text { Sigala et al. } \\
(2005)\end{array}$ & $\begin{array}{c}\text { 93hotels of } 3 \text { star, } \\
\text { United Kingdom }\end{array}$ & $\begin{array}{l}\text { - Number of rooms } \\
\text { - Staff payroll of customer department } \\
\text { - } \text { expenses } \\
\text { - Personnel expenses of the } \\
\text { accommodation department } \\
\text { - Other expenses of the accommodation } \\
\text { department } \\
\text { - Total demand variability }\end{array}$ & $\begin{array}{l}\text { - Ratio of average occupancy } \\
\text { - Number of stays } \\
\text { - Income non related with } \\
\text { accommodation }\end{array}$ \\
\hline $\begin{array}{l}\text { Chiang et al. } \\
(2004)\end{array}$ & $\begin{array}{c}25 \text { hotels of } 4 \text { and } \\
5 \text { stars } \\
\text { Taiwan, } 2000\end{array}$ & $\begin{array}{l}\text { - Number of rooms } \\
\text { - Dining and bar area } \\
\text { - Number of employees } \\
\text { - Total expenses }\end{array}$ & $\begin{array}{l}\text { - Performance index } \\
\text { - Revenue from food and } \\
\text { drink } \\
\text { - Other income }\end{array}$ \\
\hline $\begin{array}{c}\text { Barros y } \\
\text { Alves (2004) }\end{array}$ & $\begin{array}{l}42 \text { state-owned } \\
\text { hotels Portugal, } \\
\text { 1999-2001 }\end{array}$ & $\begin{array}{l}\text { - Full-time workers } \\
\text { - Staff costs } \\
\text { - Book value of property } \\
\text { - Operating expenses } \\
\text { - External expenses }\end{array}$ & $\begin{array}{l}\text { - Sales } \\
\text { - Number of clients } \\
\text { - Number of stays }\end{array}$ \\
\hline $\begin{array}{l}\text { Hwang and } \\
\text { Chang } \\
(2003)\end{array}$ & $\begin{array}{c}45 \text { hotels of } 4 \text { and } \\
5 \text { stars Taiwan, } \\
\text { 1994-1998 }\end{array}$ & $\begin{array}{l}\text { - Number of full-time workers } \\
\text { - Rooms available } \\
\text { - Dining Area } \\
\text { - Operating expenses }\end{array}$ & $\begin{array}{l}\text { - Income and breakfast } \\
\text { - Revenue from food and } \\
\text { drink } \\
\text { - Other income }\end{array}$ \\
\hline $\begin{array}{l}\text { Brown and } \\
\text { Ragsdale } \\
(2002)\end{array}$ & $\begin{array}{l}46 \text { hotels from } \\
\text { consumer } \\
\text { interviews, } \\
\text { United States }\end{array}$ & $\begin{array}{l}\text { - Average price } \\
\text { - Efficiency of service of employees } \\
\text { dedicated to check-in and check-out } \\
\text { - Maintenance } \\
\text { - Total number of hotels in the U.S. } \\
\text { - Total number of rooms in the U.S. }\end{array}$ & $\begin{array}{l}\text { - Customer satisfaction } \\
\text { (scale of } 0 \text { to } 100 \text { ) } \\
\text { - Total value of the } \\
\text { establishment according to } \\
\text { the client (scale of } 1 \text { to } 5 \text { ) }\end{array}$ \\
\hline $\begin{array}{c}\text { Avkiran } \\
(2002)\end{array}$ & $\begin{array}{l}23 \text { hotels } \\
\text { Queensland, } \\
\text { Australia }\end{array}$ & $\begin{array}{l}\text { - Number of full-time workers } \\
\text { - Number of part-time workers } \\
\text { - Number of beds }\end{array}$ & $\begin{array}{l}\text { - Total Revenue } \\
\text { - Ratio of occupation }\end{array}$ \\
\hline $\begin{array}{l}\text { Anderson et } \\
\text { al. }(2000)\end{array}$ & $\begin{array}{c}48 \text { hotels } \\
\text { United States }\end{array}$ & $\begin{array}{l}\text { - Full-time workers } \\
\text { - Number of rooms } \\
\text { - Expenses related to leisure } \\
\text { - } \text { Othenses for meals and drinks }\end{array}$ & $\begin{array}{l}\text { - Total Revenue } \\
\text { - Other income }\end{array}$ \\
\hline
\end{tabular}




\section{Annex 1 (continue)}

Review of Input and Output Variables Used in the Dea Literature

\begin{tabular}{|c|c|c|c|}
\hline $\begin{array}{c}\text { Johns et al. } \\
\text { (1997) }\end{array}$ & $\begin{array}{c}15 \text { hotels, } \\
\text { United Kingdom }\end{array}$ & $\begin{array}{l}\text { - Number of rooms available at night } \\
\text { - Total working hours } \\
\text { - Catering expenses } \\
\text { - Costs of public services (water, } \\
\text { electricity, ...) }\end{array}$ & $\begin{array}{l}\text { - Number of rooms sold per } \\
\text { night } \\
\text { - Total number of clients } \\
\text { - Income from beverage }\end{array}$ \\
\hline $\begin{array}{l}\text { Morey and } \\
\text { Dittman } \\
(1995)\end{array}$ & 54 hotels & $\begin{array}{l}\text { - } \text { Cost of rooms } \\
\text { - Energy expenditure } \\
\text { - Salaries } \\
\text { - Salaries and expenses for non-salary } \\
\text { publicity } \\
\text { - Fixed costs }\end{array}$ & $\begin{array}{l}\text { - Total sales } \\
\text { - Level of service provided } \\
\text { - Market share } \\
\text { - Growth rate }\end{array}$ \\
\hline
\end{tabular}

Source: Own elaboration. 
